University of Rhode Island

DigitalCommons@URI

The Rhode Island Current Conditions Index

Economics

$9-2006$

\title{
Rhode Island Current Conditions Index - September 2006
}

Leonard Lardaro

University of Rhode Island, lardaro@uri.edu

Follow this and additional works at: https://digitalcommons.uri.edu/ricci

Part of the Econometrics Commons

Terms of Use

All rights reserved under copyright.

\section{Recommended Citation}

Lardaro, Leonard, "Rhode Island Current Conditions Index -- September 2006" (2006). The Rhode Island Current Conditions Index. Paper 74.

https://digitalcommons.uri.edu/ricci/74

This Article is brought to you for free and open access by the Economics at DigitalCommons@URI. It has been accepted for inclusion in The Rhode Island Current Conditions Index by an authorized administrator of DigitalCommons@URI.For more information, please contact digitalcommons-group@uri.edu. 


\section{GURRENT}
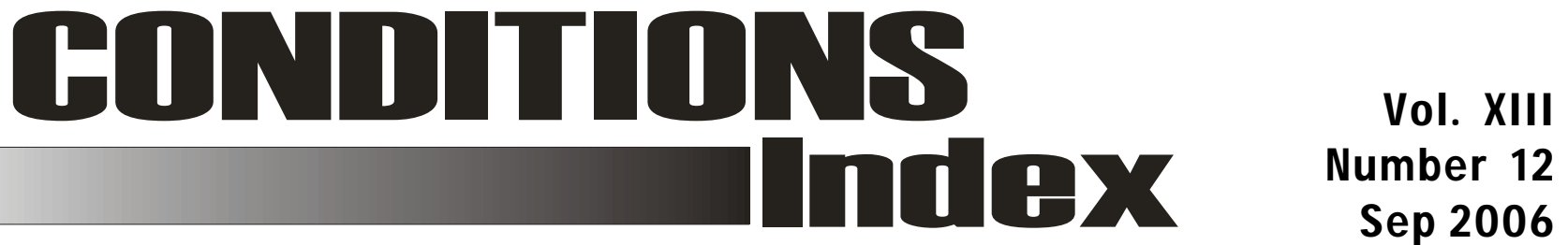

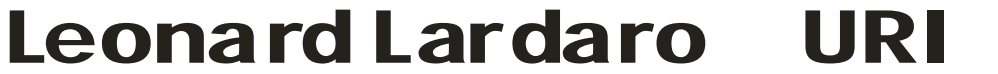

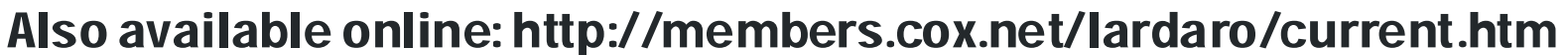

While the slowing pace of national economic activity continues to pose problems for Rhode Island, our state's economic performance managed to move "out of the doldrums" at the end of the third quarter. The Current Conditions Index for September rose from its sub-par August value of 42 to $58-$ back into the expanding activity range, as seven indicators improved. More importantly, the $\mathrm{CCl}$ beat its year-earlier value for the first time since April. Ironically, this occurred as two very strong indicator performances were offset by two very poor performances.

The two best performers this month were Retail Sales and US Consumer Sentiment. Retail Sales rose by a strong 9.6 percent in September, following two consecutive months of declines. This was its strongest rate of increase since January. US Consumer Sentiment rose by a very healthy 11.0 percent, its first improvement in well over a year. Not surprisingly, both of these indicators are related. In September, falling energy prices gave consumer confidence a much-needed boost, which along with the prospect of improving finances, stimulated Retail Sales.

\begin{tabular}{lc}
\multicolumn{2}{c}{ CCI I ndicators - \% Change } \\
Government Employment & -0.3 \\
US Consumer Sentiment & $11.0 \mathrm{Y}$ \\
Single-Unit Permits & -43.4 \\
Retail Sales & $9.6 \mathbf{Y}$ \\
Employment Services J obs & $0.9 \mathrm{Y}$ \\
Priv. Serv-Prod Employment & $0.6 \mathbf{Y}$ \\
Total Manufacturing Hours & -3.3 \\
Manufacturing Wage & $2.7 \mathbf{Y}$ \\
Labor Force & $1.2 \mathbf{Y}$ \\
Benefit Exhaustions & $-6.1 \mathbf{Y}$ \\
New Claims & 20.3 \\
Unemployment Rate & 2.0 \\
\multicolumn{1}{c}{ Y = I mproved Value } &
\end{tabular}

September's worst performers involved housing and labor demand. Single-Unit Permits, which reflects new home construction, fell by an amazing 43.4 percent in September, its sixth consecutive monthly decline. For the entire state, there were only 97 permits in September! New Claims for Unemployment Insurance, which measures layoffs, rose sharply in September, by 20.3 percent. New Claims have now risen for four of the last five months, effectively ending its prior downward (improving) trend. On the other end of the layoff spectrum, however, Benefit Exhaustions, which reflects long-term unemployment, continued to improve, falling by 6.1 percent in September.
Rhode Island's manufacturing sector continued to generate conflicting signals. The Manufacturing Wage rose by 2.7 percent in September, its ninth consecutive increase, and its strongest growth rate in several months. But Total Manufacturing Hours fell by 3.3 percent, which was its most rapid rate of decline since June. As noted over the past few months, this combination points to the likelihood that labor shortages are impacting Manufacturing Wage growth.

Employment Service Jobs, which includes the demand for "temps," grew by only 0.9 percent in September, its rate for the entire quarter. Along with this, Private ServiceProducing Employment growth remained well below a onepercent rate $(+0.6 \%)$ in September, and Government Employment fell slightly (by $0.3 \%$ ). For September, Rhode Island's national rank for payroll employment growth was \#47.

Finally, Labor Force growth remained well below its rates of growth throughout much of this year, rising by 1.2 percent in September. Our Unemployment Rate rose slightly from its value last September (from $5.1 \%$ to $5.2 \%$ ), but fell by 0.4 percentage points from its August value. It remains well above both the national rate and far from the level consistent with full employment here (of $4.2 \%$ ).

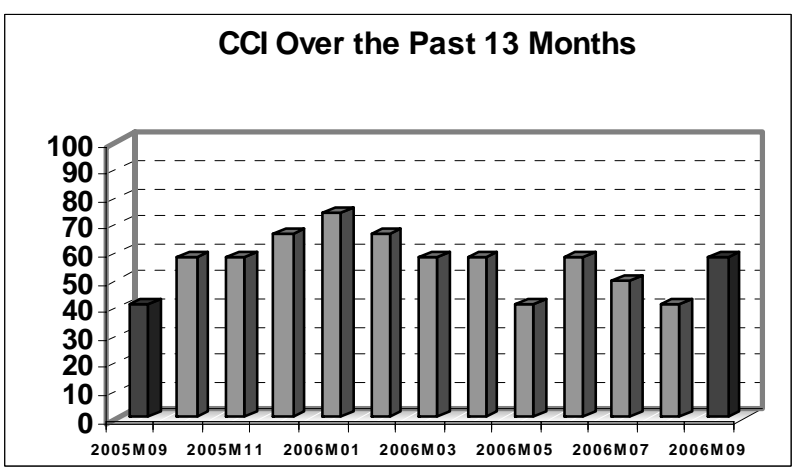

\section{THE BOTTOM LINE}

My suspicion that Rhode Island's actual economic performance was better than it looked statistically, turned out to be correct. We are now firmly in "first gear" and no longer fighting to sustain that status. Let's hope that Q4 is as kind to Rhode I sland as the end of Q3 was.

\begin{tabular}{|c|c|c|c|c|c|c|c|c|c|c|c|c|c|}
\hline & \multicolumn{1}{c}{ Jan } & Feb & Mar & Apr & May Jun Jul Aug Sep Oct Nov Dec \\
\hline
\end{tabular}

